\title{
“OUR BEER IS BETTER THAN THEIRS": SUB-CULTURAL COMICS AS A JOKING RELATIONSHIP WITH IDENTITY ${ }^{1}$
}

\author{
Aimar Ventsel
}

\begin{abstract}
Many music-related subcultures have their own printed media known as fanzines. These journals often include comics, drawn by amateur artists who belong to the same subculture. In my article I will focus on the comics in German reggae and punk fanzines. I am going to demonstrate that besides entertainment and fun, these comics also entail a wide range of political, social and cultural messages as well as attempts to define the subculture's identity. Punk/ skinhead-comics often discuss political issues, criticize certain features of punk culture (like local patriotism), but also raise issues such as commercialization. Reggae-fanzines focus very often on stressing certain cultural traits like the use of colloquial language, behaviour patterns and dress code which are considered essential to being part of that subculture. Considering the joking, the paper reveals that similarly to South African tribes, the humour of punk and reggae fanzines hides very serious social, political and cultural issues.
\end{abstract}

Key words: comics, Germany, joking relationship, punk, reggae, skinhead, subculture

In this paper I want to discuss comics of the German reggae and skinhead subculture and look how they link with the confirmation and building of subcultural identities. I want to display that in the analysis of sub-cultural comics we can use concepts of the "joking relationship", and also lean on the concept of "trickster" from classical anthropological theory.

In researching literature for this paper I searched academic databases to find out what has been published about subcultures' comics. Using key words like "subculture", "sub-cultural", "cartoon" and "comic(s)" I found literally nothing that could have been useful for my own paper. Most results I received were about the subculture of comics, i.e. comic fans' subcultures. For example, there are studies about how comic fans copy the dress and behaviour of their comic heroes (e.g. Tsutsui 2008). I do not want to argue that no research has been done about comics of subcultures but I was not able to locate examples. It shows that scholars of cultural studies, subculture studies or sociology work- 
ing on (youth) subcultures have had little interest regarding this aspect of subcultures' life as it seems that even the comics themselves are not very popular among scholars. In his 2004 published MA thesis James H. Frail Jr. laments "Comic books are a niche within society that has been largely ignored by sociologists" (Frail Jr. 2004: 7). One reason for that - the author concludes - is that the comic book subculture is "cliquish" and "90\% male" (Frail Jr. 2004: 44-45). Perhaps another reason for the modest interest of scholars toward different aspects of the comic culture is that the "Golden Age" of comic books was before and during World War II (Wright 2001). By brief library and internet research I acquired the impression that those scholars, who work on comics in current times, focus mainly on comic books but not on comic strips that are published in journals or newspapers. However, there are few exceptions like the study of Snyder about teaching sport by using comic strips, or Helen White Streicher's study about comics and gender (Snyder 1997; Streicher 1974). In terminology, I do not differentiate comics from cartoons and see both terms as synonyms. Moreover, this is also the case in the academic literature. Generally, the term "cartoon" is often implied for the "comic strips" and "comics" are often used when talking about "comic books", but this division is not strict.

The research on subcultures dates back to the post-war years in America where the so called Chicago school begun to study the "deviant behaviour" of groups they entitled "subcultures". Such groups had different life style compared to the dominant mainstream society, hence "deviant". The emergence of the notion of subcultures, as a scientific term marking young people who established their own social and cultural niches, indicating their identity through different clothes, music and behaviour, is linked with the Birmingham school in the UK in the late 1970s and early 1980s. At the Centre for Contemporary Cross Cultural Studies at the University of Birmingham a group of Marxist scholars started to study emerging and already existing groups. The programmatic edited volume Resistance Through Rituals: Youth Subcultures in PostWar Britain (Hall \& Jefferson 1976) sums up the theoretical approach of the Birmingham school - a youth subculture is a working class based subculture that rebels against and resists the capitalist dominant mainstream culture. The sign of rebellion is creativity and their own style (Hebdige 1979; Willis et al. 1990). This style has a "meaning", it includes the aforementioned clothes, music, behaviour and sub-cultural norms. The approach of the Birmingham school is referred to as the "sub-cultural theory". Marxism and also clear boundaries between different subcultures were especially questioned by the post-subcultural theory. The post sub-cultural theory if not denies then has a very sceptical approach to the concept of resistance (Muggleton 2000). Many schol- 
ars argue that a subculture is a fluid group of people without any clearly defined dress-code and musical preferences. According to the post sub-cultural theory people rotate between styles. These groups with blurry boundaries are referred to as "neo-tribes" or "scenes" and some researchers even question their existence (Bennett \& Kahn-Harris 1999; Bennett 2002, 2004; Hesmondhalgh 2005). By questioning common absolute identification of subcultures such researchers also question the existence of sub-cultural common sense, or norms and values. In this paper I want to show that there are at least some sub-cultural norms to defend. In my approach I am not alone as in recent years we have witnessed the appearance of publications that defend the existence of sub-cultural norms and boundaries. Alan O'Connor argues that we should skip any "sub" and talk about "cultures". His position is that once youth subcultures no longer include only young people and in the case of older people, who still remain devoted to the style and music of their youth, it is not rebellious but a conscious decision and preference for a certain life style (O'Connor 2002). Before I give a short overview about German reggae and skinhead subcultures, I will make a brief introduction to the concept of the "joking relationship".

\section{JOKING RELATIONSHIP, TRICKSTER, LAUGHTER}

The joking relationship as a concept is regionally first related with East Africa, and according to academic tradition, the concept was formulated by the British anthropologist A. R. Radcliffe-Brown. In his article "On Joking Relationships" in the journal of Africa: Journal of the International African Institute RadcliffeBrown (1940: 195) wrote: "What is meant by the term 'joking relationship' is a connection between two persons in which one is by custom permitted, and in some instances required, to tease or make fun of the other, who in turn is required to take no offence...There are many varieties in the form of this relationship in different societies". According to the author, there are two different types of the joking relationship, symmetrical and asymmetrical, i.e. whether both sides make jokes about each other or only one side is allowed to make jokes at the cost of the other (Radcliffe-Brown 1940). In this article, the practice of social joking is connected with establishing and maintaining marital (sexual) relations among indigenous peoples of Eastern Africa.

However, there have been other comments on practices similar to the joking relations prior to Radcliffe-Brown. The British colonial official F. J. Pedler used the term first time in his brief note for the journal of Africa (1940). He 
commented on the article of French anthropologist Denise Paulme in the same journal on practices among native people of East Africa where people from different tribes make jokes about each other (Palmer 1994, Paulme 1939). The article of Radcliffe-Brown, where he correctly stated that "some general theoretical discussion of the nature of these relationships may be of interest to readers of Africa" (Radcliffe-Brown 1940: 195), initiated vivid discussion among scholars. For instance, Charles Brant reacted to the article of Radcliffe-Brown arguing that there are other causes for the joking relationship than a "potential sexual relationship" (Brant 1948: 162). Radcliffe-Brown responded to that note arguing that there are different forms of joking relationships among indigenous people in different parts of the world, different purposes for the joking relationship but the precondition for it is a certain (rather kinship based) structure and/or group formation (Radcliffe-Brown 1949). The discussion around the joking relationship did not finish with these articles and there are several works discussing this connection in different settings and regions such as death (Moreau 1944), obscenity (Thomson 1935), female dignity (Reichenbach \& Hashem 2005) or inter-tribal links (Diallo 2006; O’Bannon 2005). Among one ethnic group there can exist several types of joking relationships at the same time, each for different social and cultural settings (Schottman 1998).

However, the usage of the concept of the jocular connection is not only limited to the traditional non-European societies. Many scholars have used this concept when studying industrial societies, with the ground work being from Andrew J. M. Sykes who wrote a short article about the subject in an industrial setting. His approach leans strongly on that of Radcliffe-Brown (Sykes 1966). Sykes studied different age and sex groups in a Glasgow printing works and concludes that the joking relationship occurred only between potential sexual partners, i.e. young females and males. Further studies moved away from the linkage between the joking relationship and potential sex. Work has been carried out, investigating the joking relationship as a regulation of social relationships within the work environment, arguing that on the one hand the relationship adapts new people to the employment situation and clarifies for them the formal and/or informal rules, but on the other hand might be highly hierarchical, i.e. joking is not permitted for everyone (Bradney 1957; Duncan 1982, 1985). By investigating white and Afro-American university students, researchers found out that black males tend to tell more sexual jokes and white students more racists jokes but they also conclude that the differences were not as big as expected or that people suppose (Middleton \& Moland 1959). There is also a brilliant study about the ethnic joking relationship among Scandinavians (Gundelach 2000). The study showed that "joking relationships are common to neighbouring and culturally similar countries." According to 
the study there are clear differences how Danes, Swedes or Norwegians make jokes about their neighbours. This and similar studies bring the concept of the joking relationship to a broader level, outside of a kinship structure or clearly defined group setting.

A more general theoretical article about the joking relationship that broadens the scope was written by Mary Douglas (1968). She writes that in every period there are "many submerged jokes" understood only in the context of that period, otherwise they would be "wrongly balanced" (Douglas 1968: 366). The option for the enjoyment of a joke is the existence of a social group that understands the joke. She makes this clear with the following sentences: "The social condition necessary for a joke to be enjoyed is that the social group in which it is received should develop the formal characteristics of a 'told' joke: that is, a dominant pattern of relations is challenged by another so if there is no joke in the social structure, no other joking can appear" (Douglas 1968: 366). Douglas relates jokes with the existence of a community that shares common social norms and argues that "jokes [...] can well serve to express something about social norms." (Douglas 1968: 366)

This approach allows us to find a link between the joking relationship and the concept of a trickster. It is related to the works of Paul Radin (Radin 1972, 1999).Trickster is a comical mythological structure that breaks laws and causes a lot of confusion. Very often the trickster is a mythical ancestor of the group or some sort of cultural hero. As a rule the trickster learns of his mistakes and becomes a "good guy". Important is that according to the theory of Paul Radin, a joking relationship was used to emphasise social norms and teach them to children. Through laughter and funny stories the group formulated the concept of "wrong" and "right", something I also find in comics of German reggae and skinhead subcultures.

\section{REGGAE AND SKINHEAD SUBCULTURES IN GERMANY}

Contemporary reggae and skinhead culture might be, at first sight, very different but in reality have a lot in common. First of all, traditional skinhead culture and contemporary reggae culture are both based on Jamaican music. Worldwide reggae consumes, listens and dances to contemporary and old Jamaican music (Barrow \& Dalton 1997). Skinhead subculture developed in the UK in the 1960s when white working class youngsters started to go to Jamaican clubs and buy the music exported from Jamaica. The stereotype of a skinhead as a neo-Nazi is only partially true because in many countries of the world there still is the so called "original" or "traditional" skinhead culture, where 
adherents of the subculture listen to Jamaican music of the 1950s and 1960s called "ska", "rock -steady" and "early reggae". "Ska" music had its revival in the 1970s and 1980s when English bands such as The Selecter, The Specials, or Madness started the new wave of ska (Hall \& Jefferson 1976; Marshall 1994). Today Germany is a country that probably has the most active ska-scene in Europe. There are dozens of bands that regularly perform concerts, many skafestivals and some ska music record labels that have world-wide importance for this music, releasing not only music of German bands but also from other countries. In ska-concerts and festivals skinheads are an important part of the audience, the annual Potsdam Ska Festival in the satellite town of Berlin is the world's largest skinhead gathering, many musicians in ska bands are skinheads themselves (El-Nawab 2001).

Germany is also a very important reggae country as the biggest reggae festival in the world takes place there and as such this country is a very important performance place for international reggae artists. The world biggest reggae journal Riddim is in the German language and is issued in that country. Some German reggae record labels such as Powpow or Germaica have become very well known in recent years, producing internationally well received hits. The only internationally recognized German reggae singer called Gentleman is today the only white reggae singer who has managed to rise to the elite of this music. And last but not least, reggae dances (or parties) have a regular place in the nightlife of every German city.

In addition to musical roots, contemporary reggae and skinhead subcultures in Germany have many similar features, both value masculinity and toughness. For skinheads, the male ideal is a hard working class lad, who likes beer, music, parties and football. He does not hesitate when he has to mix in a physical fight, whether in the football ground or at a concert. "He makes his stand," as it is understood in the skinhead ideology. In the reggae, the male ideal is a "rude boy" or "bad boy", a ghetto gangster. Similar to the hip-hop gangster, he is ready for a fight, loves guns and flashy girls, has money and goes to party. The gangster is always ready to make use of his gun and this is a common topic in the modern fast club reggae or dancehall music lyrics. It does not matter that many people (artists, journalists, promoters etc.) criticize violent texts of modern dancehall artists, there is a constant flow of namely "gun lyric" songs from new artists. Another sign of the masculine ideology is homophobia which is a great problem in reggae music. The homophobic texts of some artists have caused boycotts and protest action by gay and lesbian movements and cancellation of many concerts, especially in the UK and continental Europe. 
Common aspect in reggae and skinhead culture is an emphasis on dressing up. Skinheads and reggae fans - as a rule - are fetishists of certain "scene" brands and their appearance must be stylish and clean. When skinheads are dressed in British style clothes then reggae fans prefer outfits and brands worn by Jamaican reggae artists, and sometimes also hip-hop clothes. For both subcultures, knowledge about the music is very important. People should know all the relevant songs and record collecting is highly appreciated in both scenes. Disk jockeys playing rare but good records are internationally well known as original and rare reggae and ska records are expensive and a huge collection of these is a sign both of the commitment to the music, (the person is ready to spend a lot of money on the music) and knowledge (the person knows the history of the music, orientates in the jungle of small and little known record labels and knows where to buy them).

Both subcultures emphasize in their rhetoric the importance of solidarity and loyalty to friends. Skinheads build small groups that are usually called a "mob" or "firm" and have a name. These are groups of friends that meet regularly in order to go to concerts or football and such groups can also include girls. The gang culture is also essential for the Jamaican dancehall reggae culture. Many new artists come from a certain ghetto area of Kingston or another Jamaican urban centre and reflect it in their songs. Germany does not have a particular reggae gang culture but since locality is very important for Germans then loyalty to regional artists or DJs is also very important in dancehall culture. In the widest sense, collectivity is important in both subcultures. Both subcultures use the word "Szene" (scene) to describe their subculture. The word "scene" is internationally widely used in the language of subcultures and means the assembly of different music related institutions and persons. The 'scene' are people who form a certain subculture, the clubs where events take place, bands, record stores, sometimes even book and clothes stores (Cohen 1999; Wall 2006). With their song texts many bands and artists express their loyalty to the scene, the scene is often seen as a "brotherhood", and bands or artists after the last song of the performance usually thank their audience for coming to the concert and "supporting the scene".

Of course there are also differences between both subcultures. Skinhead ideology greatly values local patriotism, including the fact that one has to be a loyal follower of a local football team. One expression of local patriotism is that people tend to prefer their local beer. In Germany, where almost every town has its own brewery, local beer is an important part of regional identity. The particularity of reggae culture is that live performers are not as important as DJs as the latter tend to form crews that are called the "soundystem". Every 
sound system has its name, often also a logo. The sound systems are the main media for introducing and popularizing new music. The tradition of the sound system culture is that sound systems record special versions of popular and well known songs called a "dub plate". The texts of the "dub plate" are slightly changed so that the singer also announces the name of the sound system and the DJs that are behind it. Producing dub plates is an important source of money for reggae singers, because voicing a sound system dub plate is expensive. Therefore this is a matter of prestige as to which sound system has better quality dub plates from old or new songs. The sound-systems often organize sound system competitions called "sound clashes", where different sound systems compete with each other regarding which has better and more dub plates.

\section{FANZINE: SUBCULTURE MEDIA}

For a long time subcultures did not have their own media as the mainstream press very often ignored and condemned the music and did not advertise upcoming events. In England, with the coming of punk there also appeared a new forum of the sub-cultural media, a self prepared music journal. This type of print media is called fanzine, a word put together from terms "fan" and "magazine". Fanzine usually follow the ideology of "D.I.Y" or "do it yourself" (Galenza \& Havemeister 2005; Haenfler 2006; Leblanc 2001; Mader 1996; O'Connor 2008; O’Hara 1995; Westhusen 2005a, 2005b). Classical fanzines are cheap, usually being a copy machine produced journal of the sub-cultural music culture and sold during concerts or in special record stores. People who make fanzines usually belong to the elite of the subculture being in one group with well known musicians, record label owners and other persons having high "sub-cultural capital" (Thornton 1996). Fanzines receive free CDs for reviewing and most fanzine makers also have free access to concerts, because they advertise in advance and review them afterwards.

For this paper I chose a few comics from German skinhead-punk fanzines SkinUp and Plastic Bomb and the reggae fanzine Riddim. SkinUp was the biggest skinhead magazine in the German fanzine history and existed in the second half of the $1990 \mathrm{~s}$, as a monthly magazine, and every issue sold 2,5003,000 copies. SkinUp was a traditional skinhead publication, distancing itself from the right wing skinhead culture and issuing many articles about skinhead or Jamaican music culture. Due to the personal problems of one of the editors it ceased to exist at the end of the 1990s. Plastic Bomb is a well known and important punk, ska, skinhead fanzine today. As mentioned earlier, it also 
includes articles about politics, but the dominant part of the magazine is about the music, i.e. band interviews, record and concert reviews. Riddim is today probably the biggest existing reggae journal in the world. Riddim also includes the aforementioned articles about music history, interviews and reviews and German reggae album and singles' charts which is very important for the sound system DJs. All these journals had or still include comics.

Fanzines have their own very special aesthetic and here one can notice differences between punk/skinhead and reggae fanzines. The covers of reggae fanzines and journals are more similar to average mainstream music magazines. Usually a picture of some artist or a band decorates the cover. This artist is also the subject of the title story. In skinhead/punk journalism one can observe more irony as very often the fun already starts on the cover. The issue of the German punk/skinhead fanzine Plastic Bomb has a cartoon where a young school student writes on the blackboard "I should not name Dim Records a fucking scum mail order". Beside the students stands a baldhead skinhead with a baseball bat. Every scene insider recognizes this skinhead as a Nazi because he wears a polo shirt with the number " 88 " on it. The number " 88 " is very wide spread among the right wing scene and means "Heil Hitler" ( $\mathrm{H}$ is the 8th character in alphabet). This cover picture refers to an actual discussion within the German punk/skinhead scene. The Dim Record is a German record label and mail order that sells right wing music. In the year 2002 there was a lot of discussion in German speaking fanzines whether Dim Records and other mail orders that sell Nazi music are "correct" and to which extent this can be tolerated. Dim Records itself published in many fanzines letters arguing that they are not right wingers but support freedom of mind and people's free choice. Another typical picture of a skinhead fanzine cover is one from SkinUp from summer 1996. The picture shows a skinhead standing up to his knees in a hill of empty beer bottles drinking another beer (see Fig. 1). For a skinhead this picture

Figure 1.

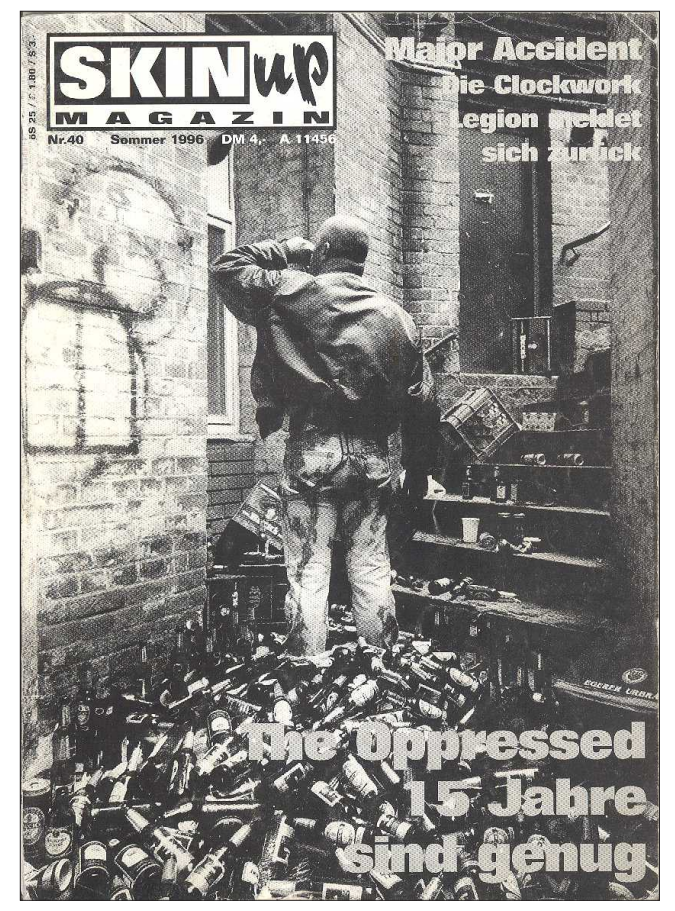


is a funny play with the subculture's ideology that has a strong connotation on partying and alcohol consumption. Excessive beer drinking is usually associated with the working class culture and rough behaviour, both idealized by skinheads as juxtaposition with neat middle class culture.

Although in the days of the internet many fanzines have moved online, paper fanzines continued to be published all over the world. Fanzines do not only cover current music events, records or artists but they also publish details on social issues or historical articles about subcultures and their situation. It is not uncommon that many famous music journalists start at fanzines. Moreover, many respected academics have also written or still write for fanzines such as the well known German black subcultures' specialist Werner Zips who, besides producing academic books and articles about hip-hop, reggae or urban African sub cultures, (Zips \& Kämpfer 2001) often also writes for the Riddim. In modern times well established fanzines are printed in colour and often include a free CD.

\section{THE COMICS OF THE SUBCULTURE}

The comics in SkinUp, Plastic Bomb and Riddim deal with issues relevant to the subculture. Through humour and satire the comics relate to the norms of the subculture and the behaviour of people involved therein. As a rule, such cartoons in fanzines are drawn by amateur artists who are not paid for this. Often they are tattoo artists who are well known in the scene and who - besides tattooing people - also collect music and attend concerts. In short, such people are well informed about the scene's life and belong to a sub-cultural elite.

One cartoon series, "Rock Steady" in the SkinUp fanzine, tells the story of a ska band. In one of the drawings the band has released their first single and as it is usual in the underground music circuit, band members try to sell records by themselves. They are pretty unsuccessful until a posh car stops and the driver buys all records. Band members are very happy and try to guess what happens now. They hope that the person who bought all records was a representative of a record company who will make the band famous. The final picture of the comics shows how rich people use singles as shooting targets (see Fig. 2). Another cartoon from SkinUp shows the band giving a concert outside of their town. The band drives to the club and the whole journey and concert is shown in a very funny way as at the end they complain about the quality of the local beer. Unfortunately the microphone is working, people in the audience 

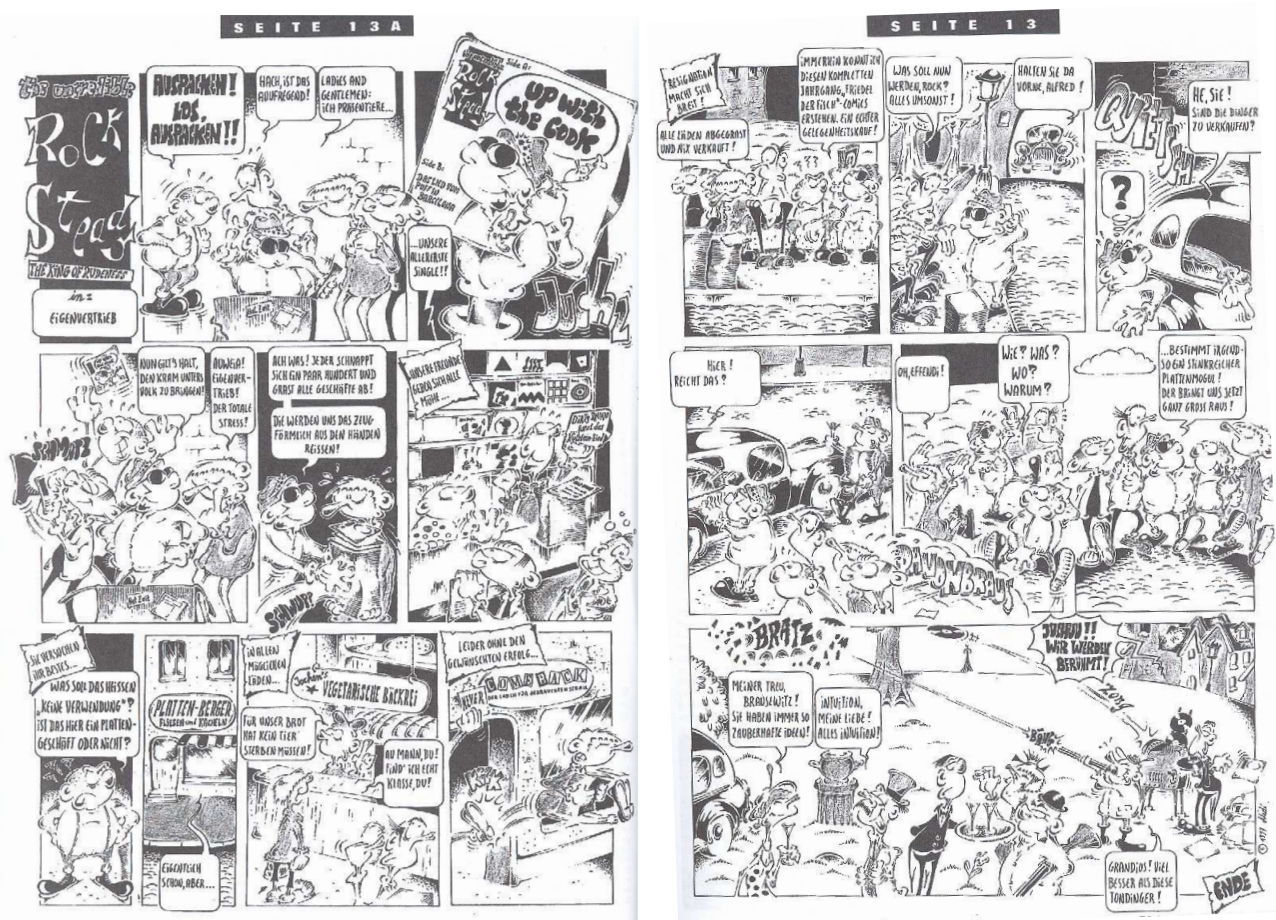

Figure 2.

hear it and are offended so the final drawings show how the offended crowd hunts the band who escapes toward Egypt.

In the comics of the Riddim magazine the central figure is a crab and a DJ Puppah Cadbury. The DJ is a fanatic music lover who plays the music in clubs and has a huge record collection. In one of the cartoons, the DJ is having a sound clash with Jesus in heaven. Playing better songs, the DJ beats Jesus. The second half of the comic strip is a discussion between different people as to why Jesus lost. Another comic strip about the DJ Puppah Cadbury is the DJ introducing his marvellous house - the fridge is full of Jamaican food (Jerk chicken) and Guinness beer, very popular in Jamaica. One room is empty because somebody had to "feng shui" it but stole all the furniture and left it empty. The last two rooms are full of an unorganized record collection and sound tapes, i.e. soundystem recordings. All the discussion is held in the Jamaican vernacular English or Patois, which is also used by most non-Jamaican reggae DJs as a sign of being a "true" reggae fan. 


\section{LAUGHTER AND SOCIAL NORMS}

The afore-mentioned comics are full of sub-cultural codes and are therefore understandable for persons who know the inner dynamics and norms of the subculture. In the Rock Steady cartoons problems are discussed regarding an underground band and the music ethos. For a young band, their first record release is a big event so disappointment that nobody is interested in buying the record is great. And when somebody buys all the released records, the band thinks that they have "made it". At the same time, the comics emphasize the alienation between underground music scene and the upper class world. The last picture shows the difference in values between these worlds - singles that are collector items for music fans are used as shooting targets. In yet another cartoon, the daily life and banality of a touring underground band is being demonstrated, mocking also the local patriotism of skinheads - an offence regarding the local beer or football is often taken personally. In comics of the Riddim magazine are demonstrated the rhetoric of the reggae music culture and its cultural values. Sound clashes are a matter of wide discussion within the subculture, similar to how football fans discuss games. Record collections are a symbol of the commitment. Stolen goods symbolize that in the reggae culture it is very common that "bad boys" try to use wealthy people in their own interests, cheat them and make profit of the relationship.

Cartoons in fanzines are made by people belonging to a subculture for people who belong to the same subculture. Such comic strips mock behaviour, language and norms that are important for the subculture. A classic theory of the joking relationship states that jokes are made about the "other" (e.g. RadcliffeBrown 1940). Further development of the theory does not exclude inner-group jokes as they just must follow the "rules of collective" (Duncan 1982; Bradney 1957). As Mary Douglas wrote, jokes must be correctly balanced (Douglas 1968: 366). Looking at sub-cultural comic strips, this is exactly the case. Janis L. Edwards and Carol K. Winkler argue, in their article about the editorial cartoons mocking the well known American photography of Iwo Jima ${ }^{2}$, that the "abstract symbolic" of these cartoons is well understandable because everybody in the USA knows the original picture (1997: 265). Authors use concepts of "representative anecdote" (Burke 1957, 1969) and "representative character" (Baty 1995) as theoretical reference points for their analysis. "Representative anecdote" is something that is "sufficiently generalized" to "sum up" action and reconstruct discourse (Burke 1957: 262, 1969: 61; Edwards \& Winkler 1997: 295) Baty in his book about the American national identity formulated the concept of "representative characters" that "allow for building and expressing 
forms of community" (Baty 1995: 41; Edwards \& Winkler 1997: 296). Same traits one can notice when looking at skinhead and reggae comics. Activities and characters that are essential for many members of the subculture are reduced to a simple funny picture story. There is a thin line between banality, offence and a good joke. The drawer of the cartoons must know these borders as she or he must also have a good knowledge of sub-cultural values, namely what Douglas calls the "formal characteristics" of a joke (Douglas 1968: 366). The heroes of the comics are similar to the trickster figure who ridicules important norms but dissimilar to the classic trickster the heroes of many subcultural comics do not violate rules but are too "true" followers of them. This way cartoons at the same time mock and confirm sub-cultural rules. The relationship with sub-cultural rules is - as is the classic joking relationship - serious. Rules, values and norms are central in the life of subculture, right clothes, music and behaviour is that makes one belonging to a subculture. Looking at cartoons in fanzines one observes that through humour subcultures also manifest core values of the subculture. The cover of the Plastic Bomb magazines tells a "representative anecdote" that, to be a skinhead, one has to distance himself from right wing ideas, and in SkinUp the Rock Steady cartoons put an emphasis on music that is central to almost every subculture. By ridiculing the enthusiasm of a young band about their hope for a bright future the author of the comic addresses a widely discussed issue: every young band thinks that their record is the best one in music history and has often a very uncritical opinion about the qualities of their music and chances in the record business. The comic strip in Riddim ridicules, for example, the usage of the Jamaican Patois that most white reggae sound systems do with passion trying to be more Jamaican than their Jamaican counterparts are.

Unlike the use of the Iwo Jima image in political cartoons, sub-cultural cartoons discussed in this paper do not parody well known (national, in the case of Edwards \& Winkler) symbols. Pictures are drawn with warm and soft humour and the goal of such cartoons is not to attack anybody but rather entertain and create a sense of belonging to a particular community. To understand these jokes, it helps when one is an insider in the subcultures. It is hard to explain for outsider why it is so funny to have thousands of unorganized records. Indeed, collecting records is important for the "sub-cultural capital" but there are people who take it too seriously. Being too serious means one cannot enjoy anymore the possession of the record collection and the fun of being part of the music oriented subculture, and he/she has lost their way. Such an übercollector is a "representative character" for someone who spoils the fun related with being part of the subculture. This is also the meaning of the sub-cultural joking relationship - take it seriously but not too seriously. 
The übercollector is like a Native American trickster who moves through the life committing crimes and doing silly things in order to become an ancestor of the tribe one day. Everyone in skinhead and reggae subcultures has seen how inexperienced bands and cocky DJs improve their attitude and music over years and become iconic figures in the scene, the elite everybody wants to be part of.

Another aspect of the fanzine cartoons is that they are made by (and reflects the attitude of) the sub-cultural elite. The elite are people who know better "how does it go along". They are people who already have reached their well established position within the subculture and made their silly mistakes. Such people have been in the scene for years, they know a lot of people, people know them and they possess deep knowledge of the music which is often symbolized with huge record collections. The elite of the subculture - as a rule does not have to prove their commitment to the subculture, because it is well known, in many cases through media coverage in fanzines. Therefore the elite can make jokes about "too serious" subculture members. The irony is that, by drawing and publishing sub-cultural cartoons, the elite holds and carries subcultural values and demonstrates their concern that the subculture should maintain their norms and values. Comic strips stress this ambivalent position - certain norms, values and behaviour are important to be maintained, as is the idea of the subculture as something linked with having fun and enjoying oneself. Being part of the subculture means often that people make funny mistakes or behave stupidly. This all does not mean that core values of the subculture are stupid.

\section{CONCLUDING REMARKS}

Sub-cultural cartoons are part of the sub-cultural media being very popular for fanzine makers. Average cartoons are full of insider codes and sayings, enjoyable for someone who shares values, norms and rules of the subculture. Through warm humour, cartoons often stress and discuss central issues of the subculture, such as music, politics, behaviour, inner norms and values without directly attacking or offending any particular group in the subculture. The joking relationship with the sub-cultural identity means that the drawer of the comics balances on the borderline where respect for the sub-cultural values can go over to obscenity. Heroes of cartoons are often tricksteresque persons who are usually too committed for subculture and usually do everything too seriously and properly. On the one hand, cartoons in fanzines symbolize that being part of a subculture means first of all enjoying oneself and having fun 
with people who think like you and share the same music taste and preferences. On the other hand, through humour, cartoons manifest and confirm sub-cultural values and therefore also symbolize the seriousness being part of the sub-cultural scene. Why is this joking so serious in its nature? The answer is - because, for many people in subcultures, being part of the scene is their conscious choice of the lifestyle.

\section{NOTES}

1 This research was supported by the European Union through the European Regional Development Fund (Centre of Excellence in Cultural Theory CECT). I am also in great debt to the Legal Pluralism Project Group of the Max Planck-Institute for Social Anthropology in Halle/Saale (Germany) for the possibility to use their facilities when working on this paper. Moreover, I profited much from discussions with colleagues at the institute, especially fruitful and inspiring for this paper were our conversations with Keebet and Franz von Benda-Beckmann, and Stephen Gudeman. Last but not least, I would like to thank the anonymous reviewer for useful comments.

2 The Battle of Iwo Jima (February 19-March 26, 1945), or Operation Detachment, was a battle in which the United States fought for and captured the island of Iwo Jima from the Empire of Japan during World War II. The battle was immortalized by Joe Rosenthal's photograph of raising the U.S. flag on top of the Mount Suribachi by five marines and one Navy corpsman.

\section{REFERENCES}

Barrow, Steve \& Dalton, Peter 1997. Reggae. The Rough Guide. The Definitive Guide to Jamaican Music, from Ska through Roots to Ragga. London, New York: The Rough Guides, Penguin Books.

Baty, S. Paige 1995. American Monroe: The Making of a Body Politic. Berkeley \& Los Angeles \& London: University of California Press.

Bennett, Andy \& Kahn-Harris, Keith (eds.) 2004. After subculture: Critical Studies in Contemporary Youth Culture. Basingstoke: Palgrave Macmillan.

Bennett, Andy 1999. Subcultures or Neo-Tribes? Rethinking the relationship between Youth, Style and Musical Taste. Sociology, Vol. 33, No. 3, pp. 599-617.

Bennett, Andy 2002. Researching Youth Culture and Popular Music: A Methodological Critique. The British Journal of Sociology, Vol. 53, No. 3, pp. 451-466.

Bradney, Pamela 1957. The Joking Relationship in Industry. Human Relations, Vol. 10, No. 2, pp. 179-187.

Brant, Charles S. 1948. On Joking Relationships. American Anthropologist, Vol. 50, No. 1, pp. 160-162. 
Burke, Kenneth 1957. The Philosophy of Literary Form: Studies in Symbolic Action. New York: Vintage Books.

Burke, Kenneth 1969. A Grammar of Motives. Berkeley \& Los Angeles: University of California Press.

Cohen, Sara 1999. Scenes. In: B. Horner \& T. Swiss (eds.) Key Terms in Popular Music and Culture. Oxford (UK) \& Malden (US): Blackwell Publishers, pp. 239-250.

Diallo, Youssouf 2006. Joking relationships in Western Burkina Faso. Zeitschrift für Ethnologie, Vol. 131, No. 2, pp. 183-196.

Douglas, Mary 1968. The Social Control of Cognition: Some Factors in Joke Perception. MAN, Vol. 3, No. 3, pp. 361-376.

Duncan, W. Jack 1982. Humor in Management: Prospects for Administrative Practice and Research. The Academy of Management Review, Vol. 7, No. 1, pp. 136-142.

Duncan, W. Jack 1985. The Superiority Theory of Humor at Work: Joking Relationships as Indicators of Formal and Informal Status Patterns in Small, TaskOriented Groups. Small Group Research, Vol. 16, pp. 556-564.

Edwards, Janis L. \& Winkler, Carol K. 1997. Representative form and the visual ideograph: The Iwo Jima image in editorial cartoons. Quarterly Journal of Speech, Vol. 83, pp. 289-310.

El-Nawab, Susanne 2001. Skinheads. Ästhetik und Gewalt. Frankfurt am Main: Brandes \& Apsel.

Frail, James H. Jr. 2004. Powers and Abilities Far Behind Those of Mortal Men: An Examination of the Comic Book Industry and Subculture through a Feminist Sociological Perspective. MA Thesis, Marshall University.

Galenza, Ronald \& Havemeister, Heinz (eds.) 2005. Wir wollen immer artig sein... : Punk, New Wave, HipHop, Independent-Szene in der DDR von 1980 bis 1990. Berlin: Schwarzkopf \& Schwarzkopf.

Gundelach, Peter 2000. Joking Relationships and National Identity in Scandinavia. Acta Sociologica, Vol. 43, No. 2, pp. 113-122.

Haenfler, Ross 2006. Straight Edge: Clean-Living Youth, Hardcore Punk, and Social Change. New Brunswick, New Jersey \& London: Rutgers University Press.

Hall, Stuart \& Jefferson, Tony (eds.) 1976. Resistance Through Rituals: Youth Subcultures in Post-War Britain. London: Hutchinson.

Hebdige, Dick 1979. Subculture: the meaning of style. London: Methuen.

Hesmondhalgh, David 2005. Subcultures, Scenes or Tribes? None of the Above. Journal of Youth Studies, Vol. 8, No. 1, pp. 21-40.

Leblanc, Lauraine 2001. Pretty in Punk: Girls' Gender Resistance in a Boys' Subculture. New Brunswick, New Jersey \& London: Rutgers University Press.

Mader, Matthias 1996. Oi! The Book Vol.1. Berlin: I.P. Verlag.

Marshall, George 1994. Spirit of '69: A Skinhead Bible. Dunoon, Scotland: S.T. Publishing.

Middleton, Russell \& Moland, John 1959. Humor in Negro and White Subcultures: A Study of Jokes Among University Students. American Sociological Review, Vol. 24, pp. 61-69.

Moreau, Reginald E. 1944. Joking Relationships in Tanganyika. Africa: Journal of the International African Institute, Vol. 14, pp. 386-400. 
Muggleton, David (ed.) 2000. Inside Subculture: The Postmodern Meaning of Style. Oxford, New York: Berg Publishers.

O’Bannon, Prett 2005. "Joking relationships" Can End Serious Conflicts. http:// www.collegenews.org/ x4902.xml, last accessed on 20 Nov, 2010.

O'Connor, Alan 2002. Local scenes and dangerous crossroads: punk and theories of cultural hybridity. Popular Music, Vol. 21, No. 2, pp. 225-236.

O'Connor, Alan 2008. Punk Record Labels and the Struggle for Autonomy: The Emergence of DIY. Lanham, Maryland: Lexington Books.

O’Hara, Craig 1995. The Philosophy of Punk: More than Noise!. San Francisco: AK Press.

Palmer, Jerry 1994. Taking humour seriously. London, New York: Routledge.

Paulme, Denise 1939. Parenté à Plaisanteries et Alliance par le Sang en Afrique Occidentale. Africa: Journal of the International African Institute, Vol. 12, pp. 433-444.

Radcliffe-Brown, Alfred R. 1940. On Joking Relationships. Africa: Journal of the International African Institute, Vol. 13, No. 3, pp. 195-210.

Radcliffe-Brown, Alfred R. 1949. A Further Note on Joking Relationships. Africa: Journal of the International African Institute, Vol. 19, No.2, pp. 133-140.

Radin, Paul 1972. The Trickster: A Study in American Indian Mythology. New York: Schocken Books.

Radin, Paul 1999. Right and wrong. In: R. J. McGee \& R. L. Warms (eds.) Anthropological Theory: An Introductory History. Mountain View, California: Mayfield Publishing Company, pp. 151-156.

Reichenbach, Anke \& Hashem, Fatema 2005. "Only a Third of a Banana”: Dirty Joking as an Attempt to Maintain Dignity. Anthropos, Vol. 100, No. 1, pp. 73-90.

Schottman, Wendy 1998. The joking relationship as practiced by the Baatombu of Bénin. In: E. Boesen \& C. Hardung \& R. Kuba (eds.) Regards sur le Borgou: Pouvoir et altérité dans une région ouest-africaine. Paris, Montreal: L'Harmattan, pp. 155-171.

Snyder, Eldon E. 1997. Teaching the Sociology of Sport: Using a Comic Strip in the Classroom. Teaching Sociology, Vol. 25, pp. 239-243.

Streicher, Helen White 1974. The Girls in the Cartoons. Journal of Communication, Vol. 24, No. 2, pp. 125-129.

Sykes, Andrew J. M. 1966. Joking Relationships in Industrial Setting. American Anthropologist, Vol. 68, No. 1, pp. 188-193.

Thomson, Donald F. 1935. The Joking Relationship and Organized Obscenity in North Queensland. American Anthropologist, Vol. 37, No. 3, pp. 460-490.

Thornton, Sarah 1996. Club Cultures: Music, Media, and Subcultural Capital. Cambridge/Hanover: University Press of New England.

Tsutsui, William M. 2008. Nerd Nation: Otaku and Youth Subcultures in Contemporary Japan. Education About Asia, Vol. 13, No. 3, pp. 12-18.

Wall, Tim 2006. Out on the floor: the politics of dancing on the Northern Soul scene. Popular Music, Vol. 25, No 3, pp. 431-445.

Westhusen, Mark M. 2005a. Zonen Punk Provinz. Punk in Halle (Saale) in den 80er Jahren. Halle (Saale): Verein für erlebte Geschichte. 
Westhusen, Mark M. 2005b. Zwischen Händel und Chemie. Punk in Halle, Eisleben und Dessau. In: R. Galenza \& H. Havemeister Wir wollen immer artig sein... : Punk, New Wave, HipHop, Independent-Szene in der DDR 1980-1990. Berlin: Schwarzkopf \& Schwarzkopf, pp. 334-347.

Willis, Paul \& Jones, Simon \& Canaan, Joyce \& Hurd, Geoff 1990. Common Culture: Symbolic work at play in the everyday cultures of the young. Milton Keynes: Open University Press.

Wright, Bradford W. 2001. Comic Book Nation: The Transformation of Youth Culture in America. Baltimore, Maryland: Johns Hopkins University Press.

Zips, Werner \& Kämpfer, Heinz 2001. Nation X: Schwarzer Nationalismus, Black Exodus und Hip-Hop. Wien: Promedia. 